\author{
Marianna Skoromna, \\ PhD (Candidate of Pedagogical Sciences), lecturer, \\ Oleksii Chebykin, \\ Doctor of Psychology, professor, \\ academician of the National academy of Educational Sciences of Ukraine, \\ South Ukrainian National Pedagogical University \\ named after K. D. Ushynsky, \\ 4, Fontanska doroha Str., Odesa, Ukraine
}

\title{
REVIEW OF THE BASIC STRUCTURAL COMPONENTS OF FUTURE TEACHERS' FEELINGS CULTURE
}

The paper presents the review of theoretical studies of the basic components of future teachers' feelings culture, which are individually motivational, cognitive and activity, and reflexively estimative. The detailed psychological characteristics of the distinguished components in terms of their relevance for teacher's work and professional training is introduced. Besides, it has been found that feelings culture is determined by personal qualities and capabilities of a future teacher as well as conditions of their formation in the course of living and mastering the profession. In the course of training, the formation of the above-mentioned components is facilitated by creating favourable psychological climate in a student group, integration of subjects relating to socio-humanitarian and psycho-pedagogical cycles; simulation of special emotive situations in training and education process.

Keywords: future teachers' feelings culture, art of teaching, teacher's work, emotional intelligence.

Problem statement. Feelings culture is an extremely important component of every teacher's pedagogical excellence. Pupils perceive consciously or subconsciously teacher's demonstration of his/her feelings culture in the educational process as a basis for the formation of their own culture.

According to numerous research works and our observations, teachers sometimes demonstrate such culture of feelings that causes certain deterioration in the relations with pupils, conflicts and other unfavorable emotional expressions. Unfortunately, theoretical bases of forming the culture of feelings in future teachers as well as its manifestations in teacher's day-to-day work are currently understudied. For the most part, there are a number of research works in psycho-pedagogical literature, which rather actualize the problem than offer the way of solving some of its aspects. Such a situation complicates the process of training future teachers in terms of forming their culture of feelings.

For the foregoing reasons, the aim of the paper is to investigate the structure of future teachers' feelings culture.

The aim involves the task of identifying basic structural components of future teachers' feelings culture. We supposed that the identification of such a structure would make it possible to improve the process of forming culture of feelings in future teachers in the course of training.

As the main research methods, we used academic literature review, generalization of existing theoretical and empirical data.

Major content. The analysis of various data $[5 ; 8 ;$ 13] concerning the structure of future teachers' feelings culture has made it possible to distinguish three components in its structure: individually motivational, cognitive and activity, and reflexively estimative.
In our opinion, the important element of the first component is axiological attitude towards teacher's work, which, according to investigations [15, p. 400], is a special kind of adults' community service that is deliberately aimed at preparing the younger generation for life according to economic, political, moral, and aesthetic aims. This fact gives reasons to consider it as seamless, task-oriented part of the educational process aimed at the development of a child personality. In our paper, it is also considered as a certain type of community activities targeted at transfer of experience and culture accumulated by the mankind from the older generation to the younger one as well as creating conditions for their personal development and preparation for fulfilling social roles determined by the society.

As noted by V. Kurok, professional activities demand teacher's awareness of the significance of his/her own role in the society, deep knowledge and positive motivation to do his/her job as long as inspiration and creative research are impossible without it; the ability for appropriate observation over pupils' cognitive work, encouraging their mental development as well as development of cognitive interests, capabilities and independence in learning.

Based on the research results [19, p.125-126], it can be stated that a teacher should consider his/her work as a part of his/her lifestyle, develop positive attitude to it through individual experience enriched by innovative pedagogy. Consequently, we suppose that axiological attitude to teacher's work causes satisfaction with it; otherwise, it is impossible to conduct training and educational process to a high professional standard. Job satisfaction, conscious professional attitude, acknowledgement of one's own efficiency, pertinence and practicality facilitate professional optimism, which is a certain emotional state 
that contributes to self-fulfillment, self-actualization in the career [17, p. 16]. It should be added that it is impossible for a teacher to develop pupils' satisfaction with learning, their cognitive interests, culture of feelings without job satisfaction. In view of the aforesaid, it can be stated that axiological attitude to teacher's work is a necessary element of individually motivational component in the structure of future teachers' feelings culture.

Next element of the above-mentioned component is teacher's empathy. The essence of this quality characterizes the understanding of relations, feelings, mental states of other people in the form of compassion. Empathy is usually associated with accepting others as they are. Some experts call it emotional response to other people's emotional experience.

In the research works devoted to empathy, two principal research trends were distinguished: cognitive and affective. For example, the representatives of the first one [11] consider empathy as an intellectual process of understanding another person by means of analyzing personal qualities and define it as realization of another person's inner world.

At the same time, the representatives of the affective trend [4] consider empathy as an emotional state rising as a response to other person's emotional experience, as an ability to be concerned about his/her emotional state. Furthermore, the scientists point out at the fact that the process of empathy development can be characterized as follows: from catching other person's mood to separating one's own emotions from other person's in one's consciousness; from compassion based on self-identification with another one to compassion based on the need for his/her well-being; from feeling with another one to taking into account the states, feelings and wishes of other people.

Other research works [9] outline the wide range of empathy manifestations. It varies from total immersion into the world of communication partner's feelings (i.e. not just understanding someone's emotional state, but experiencing his/her feelings, compassion; in this case it is called affective or emotional) to more abstract and impersonal understanding of communication partner's emotional experience without significant emotional involvement. These approaches make it possible to distinguish different levels of empathy: compassion (when a person experiences emotions identical to the partner's), sympathy (emotional response, motivation to help the partner), affection (kind and friendly attitude towards other people).

Without any doubt, it is necessary to develop empathy in teacher's work. It was emphasized by V. Sukhomlynskyi who considered empathy as a professionally important quality of a teacher. In particular, he thought that, "a teacher should begin with a simple and at the same time the most difficult thing - with the formation of the ability to feel another one's state of mind, to be able to take the place of another person in different situations". Also, the author confirmed that the one who is impervious to others will remain impervious to oneself: it will be impossible for such a person to obtain the most important thing in self-education - emotional evaluation of his/her own deeds [21].

Therefore, having generalized the research works results, it can be stated that empathy as an ability to feel emotional states of other people, particularly pupils, the understanding of their feelings, needs and values as well as rendering help and support to them is an important element of future teachers' feelings culture.

In teacher's work, it is also important to take the responsibility for relationships with others, which is distinguished as an element of individually motivational component. In various research works, it is also described at the level of social responsibility and manifested in the following traits: preciseness, punctuality, accuracy in performing one's duties, readiness to be responsible for the consequences of one's own deeds, honesty, justice. It can be also characterized by some specific emotional and volitional traits, such as the ability to sympathize, sensitivity to other people's grief or joy; some volitional qualities - insistence, stoutness, courage, endurance, etc.

In research works by $\mathrm{O}$. Kvasha [12], responsibility is considered closely connected with self-control, and it is stated that there is an internal locus of control (when a person takes responsibility for his/her own deeds, actions) and the external one (when a person thinks that his/her behaviour is determined by external factors, other people or circumstances). People of the first type, in the author's opinion, are characterized by acknowledgement of kindness, tolerance, insistence and great effort when studying and working, initiativity, self-criticism, proneness to analyzing one's deeds, confidence, the ability to get the job done, explain failures, etc. People of the second type are characterized by rudeness, proneness to conflict, lack of initiative, egoism, malevolence, envy and expressed irresponsibility, etc.

In this regard, it should be noted that V. Sukhomlynskyi always drew teachers' attention to the fact that their job is notable for particular significance and responsibility. For example, in his work " 100 recommendation for a teacher" he wrote that, "One of the most important peculiarities of teacher's creativity is that it is aimed at a child who is constantly changing being new all the time, who is different today from the child he/she was yesterday. Our work involves the formation of a person, so our responsibility cannot be compared with anything else" [21, p. 421].

This issue was more carefully considered in the works by I. Bekh [2], who found that in teacher's work the sense of responsibility combines teacher's professional efforts with the general intellectual and sensual state of a pupil. Age-specific educational standards orient the direction of teacher's professional responsibility and at the same time specify its degree depending on the fact, whether they were accepted or not. This is the traditional professional instruction for this important formation in the structure of teacher's mastery. In addition, it is emphasized that professional responsibility of a teacher should correspond to his/her ability to forecast moral formation and development of a pupil. If teacher's educative activities resonate with the pupils and provide attaining of the goals, his/her forecasts concerning moral development 
become an efficient mobilizing force [2].

Another point of view is demonstrated in the work by O. Kvasha [12]. The author thinks that personality's activities are significantly influenced by the soul, which combines rational and irrational components; interaction of the latter facilitates responsibility. Consequently, responsibility arises when properly disposed mind is in accord with feelings and vice versa - feelings are in accord with the mind.

Therefore, responsibility is a necessary professional quality of a teacher, which is represented in his/her culture of feelings; it should be taken into account in academic training of students.

Another important element is teacher's justice that facilitates building positive relationships with pupils. Justice is a synthetic scientific category that combines cognitive and axiological aspects. It embodies the possibility of the ideal as a value determined by people's behaviour as well as their rationality, that is, the ability to set goals and make their wishes and decisions reasonable, to have rational judgments about the events they are involved in.

Justice demands respect for the society and for other people, by extension. According to such an approach, justice is an important element that should be peculiar to a teacher as long as it demonstrates respect for a child as a value. It is well-known that justice is the high level of meaningfulness of simple, natural rules of morality developed by centuries-long living of the mankind.

Humanistic ideas about organization of interaction with pupils in terms of their acceptance of social and moral rules of society were studied by Lawrence Kohlberg, who thought that democratic management at school is an important educational means. He came up with the idea of creating "just communities", which was influential in education and was the basis for organizing cooperation of teachers and pupils in American universities and schools. L. Kohlberg's humanistic ideas were associated with organization of justice-based education system at schools. He considered justice as a cause of action, not a personality trait. Among the significant results of his studies were also the statements that education by means of personality's advancement from low to higher level of moral development is "education of justice" in a broad and general cultural sense of the word. In our opinion, L. Kohlberg's ideas about justice in the work of teachers who must implement it when interacting with pupils and educate this moral feeling in them can hardly be overestimated. To sum up, it can be stated that justice is an important element of individually motivational component in the structure of teacher's feelings culture.

The essential element of cognitive and activity component, in our opinion, is knowledge on feelings and their demonstration in personality's everyday life, as long as it is impossible to carry out any activities and particularly to from pupils' culture of feelings without this knowledge. O. Yakovleva thinks that perception of one's own feelings is the preconditions for realizing one's individuality. M. Kuznetsov shared her opinion and emphasized that personality's emo- tions and feelings determine predominance of positive or negative personality traits, which in their turn depend on individual typological features of a personality and educative impact. Thus, the scientist pointed out at the fact that in the teaching process, it is important to specify the conditions for harmonious development of the fundamentals of future teachers' culture of feelings. As a result, it will enhance their competence in forming skills required for controlling feelings in children (anger, anxiety, fear, guilt, shame, sympathy, pity, empathy, pride, genteelness, love, etc.); they will be able to instruct children how to understand their emotional states and their causes.

Therefore, in order to be able to carry out such activities, a teacher must have special knowledge of feelings and their role in building harmonious relationships with other people, be ready to demonstrate their feelings in a socially acceptable manner. Considering the mentioned above, pedagogical education faces the task to provide future teachers with necessary knowledge of their own feelings, to teach them to understand their own and other people's emotional states, to give the idea of the ways of demonstrating their own feelings and to improve the ability to control them.

In this respect, different researchers emphasize the fact that knowledge of rules of conduct supplemented by emotional attitude to them develop into convictions and become "inner intentions" for activities and behaviour. In his research work [2], I. Bekh noted that assisted by a teacher, a child should master "the ABC of emotions" (in our case - "the ABC of feelings"), which includes instructing how to detect feelings and emotions, associate them with corresponding facial expressions of a person and events, choose proper means of expressing one's own feelings, convey them by means of facial expressions, pantomimicry, words; educating the ability to use socially acceptable ways of responding to life events, practising the demonstration of emotional sensitivity to other people's states.

However, without sufficient knowledge on feelings culture and their role in human life, future teacher will not be able to form his/her own and pupils' feelings culture. Consequently, this knowledge is an important part of future teacher's feelings culture.

Equally important for future teachers' feelings culture is emotional intelligence. According to the conception of J. Mayer and P. Salovey [25], the latter characterizes abilities that facilitate perception and understanding of one's own emotions and emotions of other people. Other researchers consider emotional intelligence as one of the forms of recognizing person's positive attitude to the world (its evaluation as the one, where one can live successfully); to other people (as those who deserve kind attitude); to oneself (as a person capable of determining one's own life goals and is active in their achievement, as the one who deserves self-respect).

Emotional intelligence is also considered as substructure of social intelligence that includes the ability to observe one's own and other people's emotions, distin- 
guish between them and use them to control thinking and behaviour. In addition, the authors note that emotional intelligence is not opposed to the intelligence; it is not the brain's triumph over feelings, but a unique intersection of both processes.

The resulting product of emotional intelligence is decision-making based on expression and interpretation of emotions, which act as differential evaluation of events that are of personal significance. According to I. Bekh [2], emotional intelligence produces unobvious ways of activity for achieving goals and meeting the needs. As distinct from abstract and concrete intelligence that reproduces the rules of the outside world, emotional intelligence reflects the inner world and its connections with personality's behaviour and interaction with the reality.

A mixed model of emotional intelligence, according to the data obtained by D. Goleman [6], characterizes combination of cognitive capabilities and five personality characteristics: emotional states identification, understanding interrelations between emotions and actions; modulation of emotional states, control over emotions and replacement of unfavourable emotional states by the proper ones; the ability to enter emotional states that contribute to obtaining success; the ability to understand other people's emotions, be responsive to them and control them; the ability to build interpersonal relations with other people and to maintain them.

In D. Lyusin's opinion, emotional intelligence is the ability to understand one's own and other people's emotions and control them. In other words, a person can recognize an emotion (to ascertain the existence of emotional experience in oneself and in another person); identify the emotion (to determine exactly what kind of emotions is experienced by him-/herself and by another person and to choose its verbal expression); understand reasons that caused this particular emotion and the consequence it will lead to.

As can be seen, different researchers offer similar opinions concerning emotional intelligence. Based on their views, one can note the necessity of forming future teachers' emotional intelligence as an integral part of feelings culture.

Considering the fact that the job of a teacher is full of emotional experience, in the course of training future teachers should master the ways of controlling their feelings, that is, first of all, learn to control the intensity of emotions, defuse their intensive demonstrations that may cause negative consequences in relations with pupils. Therefore, emotional intelligence can be considered as an essential element of cognitive and activity component of future teachers' feelings culture.

The other important element of feelings culture is future teachers' communication skills, which are, according to Ye. Rapatsevich [20], individually psychological peculiarities of a personality that provide efficiency of communication and coexistence with other people. Communicative abilities include the ability to initiate readiness for communication, response to other's initiative; the ability to inform about one's own readiness for communication in an expressive way by means of words and facial expressions; the ability to exchange information, listen to a partner without interrupting, establish mutual cooperation; the ability to appreciate relationships, demonstrate age peculiarities, loyalty, reliability, consistency.

Considering teacher's work as a creative process, V. Kan-Kalik [10, p. 9] states that implementation of comprehensive teaching process requires communication in public; purposeful organization of communication and control over it; quick, efficient and proper orientation in changing communication conditions; proper planning and implementation of communication system, in particular, its important branch - speech impact; the ability to find communicative means appropriate to the content of a communication act, which correspond to teacher's creative individuality, communication situation and pupils' individual characteristics at the same time; the ability to feel and maintain feedback in communication regularly.

It is known that teacher's communication skills involve his/her ability to build pedagogically reasonable relationships with certain pupils, small groups and groups of pupils, parents, teachers; establish contact, choose proper tone and get along with different people in different circumstances, etc. [16]. In addition, three interrelated groups of the above-mentioned abilities were distinguished: perceptive abilities, (verbal) communication ability itself as well as abilities and skills of pedagogical technique. Perceptive abilities include the ability for perception and proper interpretation of the information on signals received from a communication partner; the ability to penetrate into other people's selfhood, see their individual characteristics and differences form others, etc. Pedagogical communication abilities, in the authors' opinion, are closely related to memory and imagination (the ability to recollect peculiarities of former communication with the class, pupils' individual characteristics, be in pupils' position and forecast their behavior; to carry out communicative attack, create the atmosphere of group search, etc.). All the above-mentioned features are considered by some researchers in terms of pedagogical technique. The latter is thought of as a combination of abilities and skills required for pedagogical stimulation of activity of certain pupils or a class as a whole: the ability to choose proper style and tone of communication, to feel the tempo, to control one's body, to convey information expressively, etc.

M. Vasylieva characterizes communicative abilities in a slightly different way, considering them to be a component of teacher's pedagogical culture. She distinguishes the following abilities: to plan communication; to determine behaviour strategy; to be included into the situation and to solve it; to be familiar with communicants; to take into account age-specific and individual characteristics of pupils; to choose communication means for different situations; to use verbal and non-verbal means of communication (gestures, facial expression, pantomimicry); to use paralinguistic (voice, tonality, pitch) and extralinguis- 
tic (speech tempo, logical stress, pauses) sign systems; to listen to an interlocutor; to use personal space ("spatial zones") in communication; to feel confident and act in non-typical and conflict situations.

The necessity for purposeful formation of communication abilities was emphasized by other researchers, who note that the methods of coming into contacts, the ability to see, feel, perceive and understand one's communication partner; knowledge of rules of social interaction between people, ways and means of verbal and nonverbal communication, etc. should be studied thoroughly and consistently. Two assumed groups of these abilities were distinguished: perceptive and productive. According to this classification, perceptive communicative abilities of a teacher include the abilities to identify and understand mental state of a certain pupil and disposition of the class (group); to allocate attention for different components of the educational process; to forecast behavior of a pupil as a communication partner; to hear and see mistakes in pupil's communicative behavior; to estimate approximate communicative skill level without testing, etc. Productive communication abilities of a teacher include the ability to create communicative atmosphere; to establish verbal contact with pupils and maintain communicative atmosphere in a group; to finish verbal contact; to regulate behaviour of a pupil as a communication partner, change functional state of a pupil in right direction and so on.

Consequently, communicative abilities are important element of cognitive and activity component in the structure of future teachers' feelings culture.

One more important element of this component is the ability to make decisions in non-typical situations. It is obvious that a teacher has to make various decisions regularly, to respond quickly to the situations arising in interaction with pupils. In the opinion of V. Chernobrovkin, decision-making is inseparable from the situation, in which a teacher is involved. Traditionally these situations are defined as problem situations. They may be considered as a correlation of circumstances and conditions of the development of individual or group's activity, which has a contradiction and no ready decision options fixed in the past experience. In this context, the ability to make right decisions is directly reflected in teacher's feelings culture. V. Riadko considers this process in a different way: he thinks that decision-making is the basis for any purposeful activities and a necessary integral component of its psychological structure. In addition, the author states that the ability for decision-making is an essential component of a personality that determines specificity of its social activity, capability for developing new life strategies, adaptation to rapid social and economic changes in the society. Decision-making involves identification of a problem situation, imaginary suggestion of various options of its soling (hypotheses); evaluation of the suggested options; choosing the one that will provide achievement of the desired result.

In the respect, A. Kuzmin [14] emphasizes that in the process of conformal decision-making students learn to predict each other's actions and intentions, interpret different elements of the situation in a similar way, master reflexive methods and abilities to correct their own and partner's activities, which makes it possible to solve the problems and establish closer professional contacts. In this case, the formation of certain intellectual and feelings culture may be observed.

Therefore, teacher's ability to make right decisions that will not do harm to pupils in non-typical situations is an important element of his/her general culture and culture of feelings.

The last component in the structure of future teachers' feelings culture is reflexively estimative that includes the following qualities: emotional self-regulation, emotional flexibility, reflexive abilities.

It should be noted that teacher's work is full of various conflict situations arising in the process of communication with pupils and their parents. Thus, when studying at pedagogical universities, future teachers should form the ability to avoid conflicts in the educational process. $\mathrm{H}$. Lozhkin thinks that conflicts demonstrate clash of incompatible views, interests, values of two or more people as well as actions that make it impossible to achieve the desired results of activities, meet essential personal needs and goals. On the other hand, proneness to conflict is a troublesome quality as long as it undermines the system of relationships between a teacher and pupils, causes the state of severe stress and dissatisfaction in the teacher.

Conflicts between a teacher and children/parents/staff, as noted by V. Sukhomlynskyi, are a huge problem for the school. In most cases, conflicts arise when a teacher thinks of a child unfairly. For this reason, he writes, "Think of a child fairly - and you will be able to avoid conflicts. The ability to avoid conflicts is one of the components of teacher's pedagogical wisdom. Preventing conflicts, the teacher is able to preserve and generate educative power of the group" [22].

Although, teacher's understanding of a situation as a conflict causes negative emotional feelings in him/her and children, such as hyper-anxiety, fear, feelings of hostility, the want to resist, prejudice, aggressiveness and so on, it makes it difficult to create positive emotional atmosphere in the class and, as a result, deteriorates normal course of the educational process.

Consequently, the ability to avoid conflicts, to overcome them successfully is an important component of teacher's feelings culture.

The other element of reflexively estimative component in the structure of future teacher's feelings culture is self-regulation. According to A. Prokhorov [18], selfregulation is control over one's psycho-emotional state that is attained due to personality's impact on itself by means of words, fancies, control over muscular tone and breathing. Self-regulation is based on realization of what is happening at every specific time point, living right there and then. Unconscious shame, sense of guilt result in anger, annoyance, aggression or depression, which are 
not motivated and explained by inconsequent reasoning and which a person tries to suppress. Demonstration of the above listed feelings is particularly harmful for the job of a teacher since they have negative impact on the emotional climate in the class and affect the relationships between a teacher and pupils.

Self-regulation of the emotional state is an important factor in teacher's work. It should be demonstrated when a teacher has to deal with a new, untypical, difficult problem that cannot be solved unambiguously or may have several alternative solutions. It is also essential when a teacher is in the state of emotional and physical tension, which determines him/her to impulsive action or in case a teacher is evaluated by children, colleagues or other people. Self-regulation of emotional states is control over both cognitive processes and a personality itself: behaviour, feelings, emotions and actions. In P. Salovey's opinion, it involves implementation of the following capabilities: identification of one's own feelings and emotions; dominating one's emotions, understanding feelings and emotions of other people.

For this very reason, E. Utkin notes that the issue of self-regulation is one of the most important psychopedagogical issues topical for both personal and professional development of a teacher.

The significance of emotional self-regulation for a teacher as a necessary element of his/her feelings culture was emphasized by B. Dodonov [7] and O. Chebykin [23]. Lack of formed emotional self-regulation or its insufficient level may lead to underperformance in teaching and education; increased proneness to conflicts in relations with pupils, their parents and colleagues, adverse health effect; facilitate high anxiety, aggressive selfdefense in the participants of the educational process.

Over the recent decades, attention of different scientists has been drawn to the problem of teacher's emotional burnout, which is characterized by sleep disturbances, decreased activity, demonstration of asthenic syndrome, increased irritability and, finally, loss of pedagogical work efficiency. Burnout as a state of physical, emotional and mental exhaustion, as noted by V. Semychenko, comes with depersonalization (cynism, negative attitude to teacher's work in general, inhuman attitude to pupils, etc.), emotional changes (feeling of exinanition, weariness), reduction of professional achievements (sense of incompetence in the professional sphere, awareness of one's failure in it). Thus, teacher's burnout demonstrates that culture of feelings and their self-regulation are formed insufficiently.

In the course of training future teachers, it is important to form their ability of emotional self-regulation, which is the necessary element of feelings culture. As stated by $\mathrm{O}$. Chebykin, self-regulation provides three important effects: soothing effect (elimination of emotional tension), recovery of psychic force (abatement of weariness symptoms), and activation effect (increase of psycho-physiological activity) [23], which, in our opinion, will contribute to the high level of future teacher's feelings culture.

One more important element of the considered component is emotional flexibility as long as teacher's work is essentially affected by his/her emotional states demonstrated in teacher's professional excellence. The issue of emotional flexibility in teacher's work was studied by a number of scientists. For example, R. Bandler and D. Grinder noted that teacher's behaviour should be flexible, which should be demonstrated by his/her reactions. The latter may indicate teacher's ability to change behaviour depending on emotive situations and circumstances, i.e. to show flexibility.

Other researchers (O. Asmakovets, L. Mitina) consider flexibility as diversity and adequateness of actions, which are demonstrated in both external and inner (psychic) forms of activity. In addition, the authors conclude that the structure of pedagogical flexibility consists of its following types: intellectual, emotional, behavioural, all of them being interrelated in professional activities. Personality's emotional flexibility, in the authors' opinion, is an integral characteristics of personality's competitive advantage, in which emotional, behavioural and intellectual personal qualities are combined harmoniously.

Practical aspects of flexibility of emotional experience were investigated by I. Bekh [2]. In his opinion, emotional rigidity (as the lack of flexibility) is extremely unfavourable factor in moral and spiritual development of a personality. It is observed when an individual does not have an experience in opposite feelings transformations (for instance, revengefulness - patience, anger - kindness). Feelings that are different in modality are generally associated with a great number of objects (people's world), and this is the way to moral primitiveness of a personality. If emotional rigidity becomes stable, such an individual may demonstrate hatred to people who respect him/her greatly.

All the facts listed above make it possible to consider emotional flexibility as an element of future teachers' feelings culture, which helps them control their inner states, overcome changes in the social environment; act and make decisions in the situations of emotional strain

The last element of feelings culture is reflexive abilities. It should be noted that theoretical background for studying reflection was provided by S. Rubinshtein in 3040 s of the past century. The researcher characterized two major kinds of people's attitude to life. In the first case, a person is involved into life; he/she demonstrates attitude to separate phenomena, not to life as a whole. In addition, he notes that the lack of such attitude to life as a whole is determined by the fact that a person remains involved into life and is not able to go beyond it in his/her mind in order to reflect upon it. Another way of living is associated with reflection that seems to stop, interrupt this continuous process of life and allows a person to overstep its limits; a person seems to take an attitude beyond it. Consequently, reflection and its opportunities are determined by a certain level of human consciousness development.

The importance of reflection was emphasized by 
A. Biziaieva, who considered reflection in several meanings. For example, in practical meaning reflection is considered as person's ability for self-analysis, comprehension and rethinking of one's own objective and social relations with the outside world, which is the necessary component of mature intelligence. In the theoretical and conceptual meaning, in the author's opinion, reflection is a form of individual's active rethinking of a certain subject of intellectual consciousness, activities, communication. In addition, maturity of reflection frees people, makes it possible to proceed from external regulation of one's own behaviour to self-regulation, conscious control over one's behaviour. The development of regulation is considered in a certain way as an object of targeted impact. Reflection allows people to see themselves through other's eyes, understand themselves, their own wishes, feelings, acts. We cannot but agree with A. Biziaieva who notes that teacher's reflexive abilities are important for applying general knowledge in certain situations arising in his/her professional activities as long as he/she has to organize interaction with pupils and demonstrate personal qualities. In other words, any learning situation should be turned into a pedagogical one as long as it provides condition for reflection formation; the latter activates teacher's activity, unlocks his/her creativity, provides an opportunity to master new methods and technologies [3].

All the research works on the issue make it possible to consider reflexive abilities as an element of reflexively estimative component of future teachers' feelings culture.

The component-based structure of future teachers' feelings culture may be represented as follows (Pic. 1):

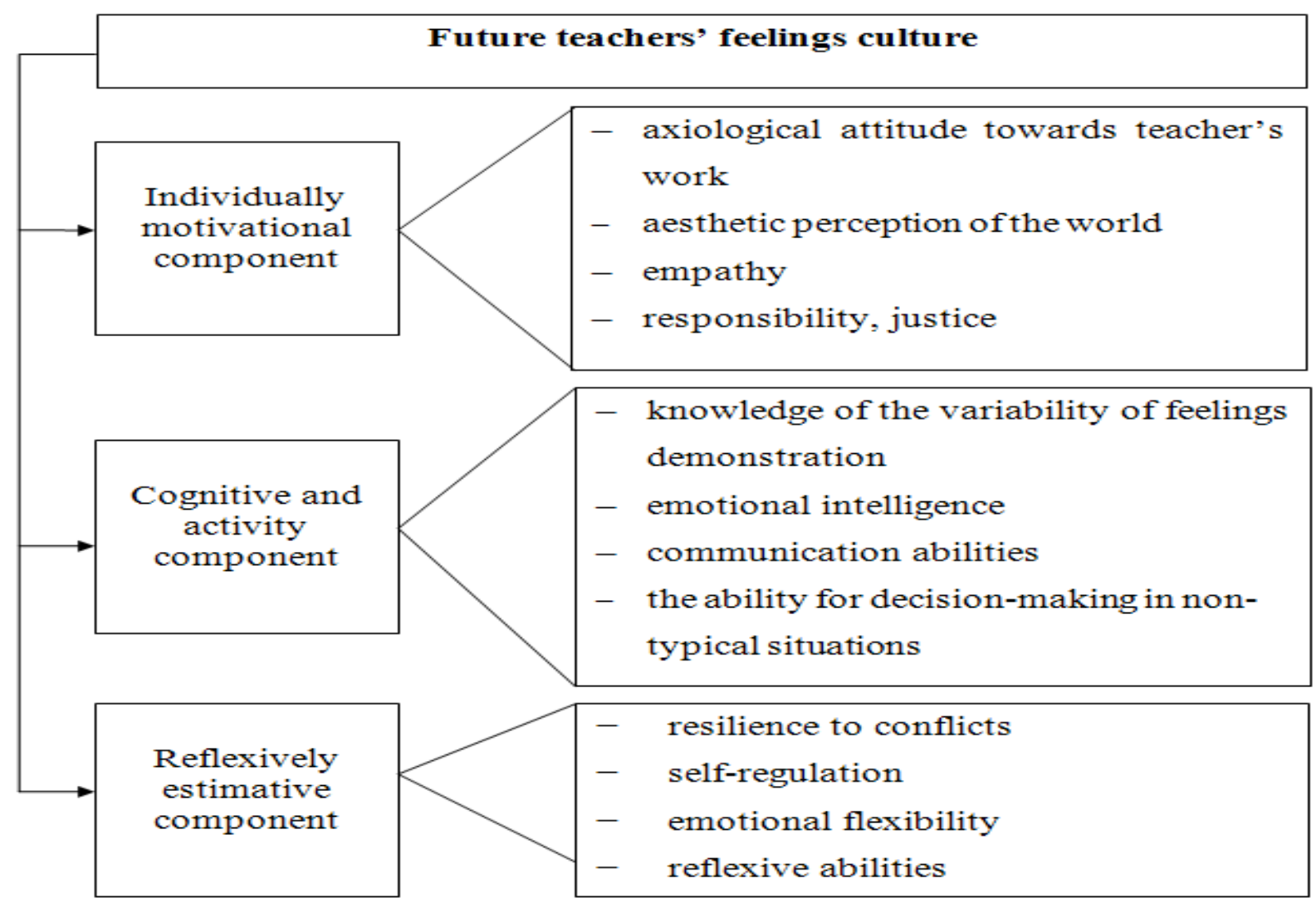

Pic.1. Component-based structure of future teachers' feelings culture

The performed review has made it possible to draw the following conclusions:

- firstly, the structure of feelings culture can be considered figuratively at the level of three components (individually motivational, cognitive and activity, reflexively estimative);

- secondly, it has been proven that feelings culture is determined by individual characteristics and capabilities of a teacher as well as conditions for their formation during his/her life and mastering the profession;
- thirdly, all the distinguished elements of future teacher's feelings culture are closely related and interdependent. In the course of training, their formation can be facilitated by implementation of corresponding pedagogical conditions: creating favourable psychological climate in a student group, integration of subjects relating to socio-humanitarian and psycho-pedagogical cycles; simulation of special emotive situations in training and education process. 


\section{ЛІТЕРАТУРА}

1. Бех І. Виховання особистості : Сходження до духовності : [наук. видання] / І. Бех. - К. : Либідь, 2006. $272 \mathrm{c}$.

2. Бех І. Д. Психологічні джерела виховної майстерності. - [Електронний ресурс]. - Режим доступу : http://pidruchniki.ws/19530610/pedagogika/ psihologichni dzherela_vihovnoyi_maysternosti_-_beh_id

3. Бизяева А. А. Психология думающего учителя : Педагогическая рефлексия / А. А. Бизяева. - Псков : ПГПИ им. С. М. Кирова, 2004. - 216 с.

4. Восприятие и действие / А. В. Запорожец, Л. А. Венгер, В. П. Зинченко, А. Г. Рузская ; под ред. А. В. Запорожца. - М. : Изд-во «Просвещение», 1967. $370 \mathrm{c}$.

5. Востриков А. А. Технология и методика культуры эмоций и чувств. Курс человековедения : [книга для учителя] : в двух частях / А. А. Востириков. - Одесса-Томск : Изд-во УГЦВ «Психопедагогика», 1994. - Ч. 2. $-243 \mathrm{c}$.

6. Гоулман Д. Эмоциональное лидерство : искусство управления людьми на основе эмоционального интеллекта : пер. с англ. / Д. Гоулман, Р. Болдис, Э. Макки. - М. : Альтена Бизнес Букс, 2005. - 301 с.

7. Додонов Б. И. В мире эмоций / Б. И. Додонов. Казань : Казан. ун-т, 1987. - 14 с.

8. Динейка К. В. 10 уроков психофизической тренировки / К. В. Динейка. - М. : Физкультура и спорт, 1987. $-63 \mathrm{c}$.

9. Емпатія. - [Електронний ресурс]. - Режим доступу : http://junction.in.ua/228

10. Кан-Калик В. А. Педагогическая деятельность как творческий процесс : Исследование субъективноэмоциональной сферы творческого процесса педагога / В. А. Кан-Калик. - Грозный : Чеч.-Инг. кн. изд-во, 1976. $-286 \mathrm{c}$

11. Карамуратова Р. Б. Психологическое исследование роли оценочной эмпатии в педагогическом процессе : дис... канд. психол. наук : 19.00.07 / Раиса Башибаевна Карамуратова. - Алма-Ата, 1984. - 214 с.

12. Кваша О. Особливості усвідомлення майбутніми педагогами соціальної відповідальності. - [Електронний ресурс]. - Режим доступу http://www.politik.org.ua/vid/magcontent.php3?m=6\&n=78 $\& c=1876$

13. Кондрашова Л. В. Формирование эмоциональной культуры старшеклассников средствами учебно-

\section{REFERENCES}

1. Bekh, I. (2006). Vykhovannia osobystosti: Skhodzhennia do dukhovnosti [Personality's education: reaching spirituality]. Kyiv: Lybid [in Ukrainian].

2. Bekh, I. D. (n.d.). Psykholohichni dzherela vykhovnoi maisternosti. - [Psychological sources of educator's mastery]. $\quad$ Retrieved from: http://pidruchniki.ws/19530610/pedagogika/psihologichnidz herela_vihovnoyi_maysternosti_-_beh_id [in Ukrainian].

3. Bizyaeva, A. A. (2004). Psikhologiya dumayushchego uchitelya: Pedagogicheskaya refleksiya [Psychology of a mindful teacher: Pedagogical reflection]. Pskov: PGPI im. S. M. Kirova [in Russian].

4. Zaporozhets, A. V., Venger, L. A., Zinchenko, V. P., \& Ruzskaya, A. G. (1967). Vospriyatie i deystvie [Education and action]. A. V. Zaporozhets (Ed.). Moscow: Izda- воспитательного процесса / Л. В. Кондрашова, Л. Е. Соколова. - Кривой Рог : КПИ, 1994. - 86 с.

14. Кузьмин А. М. Профессиональная подготовка будущих специалистов к согласованному принятию решений : автореф. дис.. на соискание учен. степени канд. пед. наук: специальность 13.00.08 «Теория и методика профессионального образования» / А. М. Кузьмин. - Саратов, 2007. - $21 \mathrm{c.}$

15. Лихачев Б. Т. Педагогика : [курс лекций] / Б. Т. Лихачев. - [Изд. 4, перераб. и доп.]. - М. : Юрайт, 2000. - 523 c.

16. Педагогика : [учебное пособие для студентов педагогических учебных заведений] / В. А. Сластенин, И. Ф. Исаев, А. И. Мищенко, Е. Н. Шиянов. - [3-е изд.]. - М. : Школа-Пресс, $2000-512$ с.

17. Проблеми психолого-педагогічного супроводу підготовки фахівців у вищій школі : матеріали всеукр. науково-практ.семінару (22 грудня 2006 р.) - Одеса : СМИЛ, 2006. - $167 \mathrm{c}$.

18. Прохоров А.О. Саморегуляция психических состояний : феноменология, механизмы, закономерности / А. О. Прохоров. - М. : ПЕРз СЭ, 2005. - 352 с.

19. Радул В. В. Основи професійного становлення особистості сучасного вчителя : [навчальний посібник] / В. В. Радул, В. О. Кравцов, М. В. Михайліченко. - Кіровоград : Поліграфічно-видавничий центр ТОВ «ІмексЛТД», 2007. -252 с.

20. Современный словарь по педагогике / Сост. Е. С. Рапацевич - Мн. : «Современное слово», 2001. $928 \mathrm{c}$.

21. Сухомлинський В. О. Вибрані твори у п’яти томах. - К. : Рад. школа, 1976. - Т.2. -670 с.

22. Сухомлинський В. О. Сто порад учителеві / В. О. Сухомлинський. - [Т.2]. - К. : «Радянська школа», 1976. $-670 \mathrm{c}$.

23. Чебыкин А. Я. Совершенствование психологической подготовки учителя к управлению эмоциональными состояниями учащихся / А. Я. Чебыкин // Эмоциональная регуляция учебной деятельности. - М., 1987. - C. 266-268.

24. Mayer J. D. The intelligence of emotional intelligence / J. D.Mayer, P. Salovey // Intelligence. - 1993. - V. 17. - P. 433-442.

25. Salovey P. Emotional intelligence / H. Salovey, J. D. Mayer // Imagination, Cognition and Personality. - 1990. - № 9. - P. 185-211.

telstvo «Prosveshchenie» [in Russian].

5. Vostrikov, A. A. (1994). Tekhnologiya i metodika kultury emotsiy i chuvstv. Kurs chelovekovedeniya [Technology and methodology of culture of emotions and feelings. Humanology course]. (Pt. 2). Odesa-Tomsk: Izdatelstvo UGTsV «Psikhopedagogika» [in Russian].

6. Goulman, D., Boldis, R., \& Makki, E. (2005). Emotsionalnoe liderstvo: iskusstvo upravleniya lyudmi na osnove emotsionalnogo intellekta [Emotional leadership: the art of people management based on emotional intelligence]. Moscow: Altena Biznes Buks [in Russian].

7. Dodonov, B. I. (1987). V mire emotsiy [In the world of emotions]. Kazan: Kazan. universitet [in Russian].

8. Dineyka, K. V. (1987). 10 urokov psikhofizicheskoy trenirovki [10 lessons of psychophysical training]. Moscow: 
Fizkultura i sport [in Russian].

9. Empatiia [Empathy]. (n.d.). Retrieved from: http://junction.in.ua/228 [in Ukrainian].

10. Kan-Kalik, V. A. (1976). Pedagogicheskaya deyatelnost kak tvorcheskiy protsess: Issledovanie subektivno-emotsionalnoy sfery tvorcheskogo protsessa pedagoga [Teacher's work as a creative process: The study of individual emotional sphere of teachers' creative process]. Groznyy: Chech.-Ing. kn. izd-vo [in Russian].

11. Karamuratova. R. B. (1984). Psikhologicheskoe issledovanie roli otsenochnoy empatii $\mathrm{v}$ pedagogicheskom protsesse [Psychological investigation of the role of axiological empathy in pedagogical process]. Candidate's thesis. Alma-Ata [in Russian].

12. Kvasha, O. (n.d.). Osoblyvosti usvidomlennia maibutnimy pedahohamy sotsialnoi vidpovidalnosti. [Peculiarities of future teachers' understanding of social responsibility]. Retrieved from: http://www.politik.org.ua/vid/magcontent.php3?m=6\&n=78 $\& c=1876$ [in Ukrainian].

13. Kondrashova, L. V., \& Sokolova, L. Ye. (1994). Formirovanie emotsionalnoy kultury starsheklassnikov sredstvami uchebno-vospitatelnogo protsessa [The formation of senior school students' emotional culture by means of training and educational process]. Krivoy Rog: KPI [in Russian].

14. Kuzmin, A. M. (2007). Professionalnaya podgotovka buduschikh spetsialistov $\mathrm{k}$ soglasovannomu prinyatiyu resheniy [Preparing future teachers for coordinated decision-making]. Extended abstract of candidate's thesis. Saratov [in Russian].

15. Likhachev, B. T. (2000). Pedagogika [Pedagogy]. $4^{\text {th }}$ ed., rev. Moscow: Yurayt [in Russian].

16. Slastenin, V. A., Isaev, I. F., Mishchenko, A. I., \& Shiyanov, Ye. N. (2000). Pedagogika [Pedagogy]. $3^{\text {rd }}$ ed. Moscow: Shkola-Press [in Russian].

17. Problemy psykholoho-pedahohichnoho suprovodu pidhotovky fakhivtsiv $u$ vyshchii shkoli [Issues of psychopedagogical support of training specialists in higher school]: Proceedings of all-Ukraine research and practice seminar. (2006). Odesa: SMYL [in Ukrainian].

18. Prokhorov, A. O. (2005). Samoregulyatsiya psikhicheskikh sostoyaniy: fenomenologiya, mekhanizmy, zakonomernosti [Self-regulation of mental states: phenomenology, mechanisms, rules]. Moscow: PERz SE [in Russian].

19. Radul, V. V., Kravtsov, V. O., \& Mykhailichenko, M. V. (2007). Osnovy profesiinoho stanovlennia osobystosti suchasnoho vchytelia [Fundamentals of professional development of future teacher's personality]. Kirovohrad: Polihrafichno-vydavnychyi tsentr TOV «Imeks-LTD» [in Ukrainian].

20. Sovremennyy slovar po pedagogike [Contemporary pedagogical dictionary]. (2001). Ye. S. Rapatsevich (Ed.). Minsk: «Sovremennoe slovo» [in Russian].

21. Sukhomlynskyi, V. O. (1976). Vybrani tvory $u$ piaty tomakh [Selected works in five volumes]. (Vols. 2). Kyiv: «Radianska shkola» [in Ukrainian].

22. Sukhomlynskyi, V. O. (1976). Sto porad uchytelevi [100 recommendations for teachers]. (Vols. 2). Kyiv: «Radianska shkola» [in Ukrainian].

23. Chebykin, A. Ya. (1987). Sovershenstvovanie psikhologicheskoy podgotovki uchitelya $\mathrm{k}$ upravleniyu emotsionalnymi sostoyaniyami uchashchikhsya [Improvement of teachers' psychological preparation for control over students' emotional states]. Emotsionalnaya regulyatsiya uchebnoy deyatelnosti - Emotional regulation of learning activities. (pp. 266-268). Moscow [in Russian].

24. Mayer, J. D., \& Salovey, P. (1993). The intelligence of emotional intelligence. Intelligence. (Vols. 17). (pp. 433442) [in English].

25. Salovey, P., \& Mayer, J. D. (1990). Emotional intelligence. Imagination, Cognition and Personality, 9, 185211 [in English].

Маріанна Володимирівна Скоромна,
кандидат педагогічних наук, викладач,

Олексій Якович Чебикін,

доктор психологічних наук, професор, академік Національної академії педагогічних наук України, Південноукраӥнський національний педагогічний університет імені К. Д. Уиинського, вул. Фонтанська дорога, 4, м. Одеса, Украӥна

\section{АНАЛІЗ ОСНОВНИХ СТРУКТУРНИХ КОМПОНЕНТІВ КУЛЬТУРИ ПОЧУТТІВ МАЙБУТНІХ ВЧИТЕЛІВ}

У представленій статті на основі теоретичних досліджень зроблено спробу визначити структуру основних компонентів культури почуттів майбутніх вчителів. У результаті дослідницького пошуку з безлічі різних складових виділено основні компоненти структури почуттів. Останні представлені у вигляді таких компонентів, як індивідуально-спонукальний, когнітивно-діяльнісний, рефлексивно-оцінний. Представлено детальну психологічну характеристику цих компонентів в аспекті їх важливості для педагогічної діяльності в навчальнопрофесійній підготовці сучасного вчителя. Крім цього, розкрито, що культура почуттів обумовлюється як множинними властивостями, так і здібностями майбутнього вчителя, а також умовами їі формування в процесі життя і освоєння педагогічної професії. Відзначено, що всі складові компоненти культури почуттів майбутніх вчителів тісно взаємопов'язані. Для їх ефективного формування важливо в процесі навчально-професійної підготовки майбутніх учителів створити сприятливий психологічний клімат у студентській групі, використовувати інтеграцію дисциплін соціально-гуманітарного та психолого-педагогічних циклів, моделювання різних емоціогенних ситуацій.

Ключові слова: культура почуттів майбутніх вчителів, педагогічна майстерність, професійна педагогічна діяльність, емоційний інтелект. 
Марианна Владимировна Скоромная, кандидат педагогических наук, преподаватель, Алексей Яковлевич Чебыкин, доктор психологических наук, профессор, академик Национальной академии педагогических наук Украинь, Южноукраинский наџиональный педагогический университет имени К. Д. Уиинского,

ул. Фонтанская дорога, 4, г. Одесса, Украина

\section{АНАЛИЗ ОСНОВНЫХ СТРУКТУРНЫХ КОМПОНЕНТОВ} КУЛЬТУРЫ ЧУВСТВ БУДУЩИХ УЧИТЕЛЕЙ

В представленной статье на основе теоретических исследований предпринята попытка определить структуру основных компонентов культуры чувств будущих учителей. В результате исследовательского поиска из множества различных составляющих выделены основные компоненты структуры чувств. Последние представлены в виде таких компонентов, как индивидуально-побудительный, когнитивно-деятельностный, рефлексивно-оценочный. Представлена детальная психологическая характеристика данных компонентов в аспекте их важности для педагогической деятельности в учебно-профессиональной подготовке современного учителя. Кроме этого раскрыто, что культура чувств обуславливается как множественными свойствами, так и способностями будущего учителя, а также условиями её формирования в процессе жизни и освоения педагогической профессии. Отмечено, что все составляющие компоненты культуры чувств будущих учителей тесно взаимосвязаны. Для их эффективного формирования важно в процессе учебно-профессиональной подготовке будущих учителей создать благоприятный психологический климат в студенческой группе, использовать интеграцию дисциплин социально-гуманитарного и психолого-педагогических циклов, моделирование различных эмоциогенных ситуаций.

Ключевые слова: культура чувств будущих учителей, педагогическое мастерство, профессиональная педагогическая деятельность, эмоциональный интеллект.

Подано до редакиіï 14.07.2016 